\title{
Selecting Appropriate Delivery System for Implementation of Green Buildings
}

\author{
Shaymaa T. Tamur ${ }^{1, a^{*}}$ and Kadhim R. Erzaij ${ }^{1, b}$ \\ ${ }^{1}$ Civil Engineering Department, University of Baghdad, Baghdad, Iraq. Email: \\ as.turkey1101@coeng.uobaghdad.edu.iq, bkadhim69@coeng.uobaghdad.edu.iq,
}

\begin{abstract}
Green buildings are considered more efficient than traditional buildings due to the incorporated techniques and the multidisciplinary specializations required to comply with their specifications, in addition to the advanced commissioning, which undergoes before handing over the buildings to the owners to ensure requirements conformance. As a result, the appropriate selection of a project delivery system acts as the essential factor that affects the performance of the project. This research aims at building a system that helps to select the best method to implement green buildings. Through studying the recent research approaches in project delivery systems, the factors that affect the selection of the optimal implementation method for green buildings have been identified; expert interviews have been done to study and analyze the main influential factors that affect the selection of the best method for implementing green buildings. The results of interviews indicate that the main influential factors are as follows: The occurrence of economic crises in the country, availability of financial capacity for the contractor and the owner, the lack of previous experience in similar projects, hiring an incompetent contractor, differences between design drawings among all disciplines, and providing qualified contractors, subcontractors, suppliers and craftsmen with sufficient qualifications early in the project. Depending on these main factors, a software system is built to choose the best delivery system for green building projects. This research encourages future works to focus on the quality and performance of green buildings and lays out the foundation for academic researchers to explore new techniques for evaluating the project delivery systems as well as supporting the decisionmakers to choose the best.
\end{abstract}

Keywords: Project delivery systems; green buildings; critical factors.

\section{Introduction}

Project delivery in green buildings is more complicated. It requires early interdisciplinary coordination and complete commitment to the green goals by the project team members. The characteristics of the proposed project and its special capabilities should be familiarized by the owner side to gain a carefully selected system that leads to cost savings and more consistent delivery systems for projects. Each project has its own characteristics, so it is important to choose the delivery method that suits it. Without a clear understanding of this concept, it is difficult for users of construction services to understand the value of the particular project delivery method for the success of the construction process, the mechanism by which projects are produced and completed, including how to select the contractor, the range of service delivered, the form of relationship with the owner, and how to pay the contractor.

\section{Project Delivery Systems PDS}

Project delivery systems define as the arrangement of all the functions and duties of the project entities involved in the contractual relationships. Through it, the project is designed and constructed for the owner in a systematic manner, including specifying the scope of the project, coordinating the various designers, contractors, and consultants, and the sequence of design and construction procedures [1]. There is virtually an infinite number of delivery systems; this paper reviews a set of the most common implementation methods. 
Design-bid-build (DBB). This method of delivering construction projects is regarded as traditional. In This method, the owner of a project has separate contracts with a design firm and a construction firm. DBB is effective in projects when the owner needs design and building services or needs continuous and experienced professional support during the design and construction process or when it requires a high degree of control in the design stage [2]. The contractor is not involved during the design stage, which is seen as a downside in this type, so it is difficult to make adjustments to the design to minimize construction costs and waste and improve the productivity of the project after occupancy [3]. This method is often criticized for the long time it takes to design and build the project, as well as the somewhat hostile relationship between the architect and the contractor, lack of innovation, and cost overruns throughout the design; the architect must estimate the cost of construction [4].

Design-build (DB). In this method, the owner signs a single contract with the design and construction contractor. A key feature of the system is clear coordination between the design and building staff, value engineering, and rapid interaction with project scope changes, but quality cannot be guaranteed to the owner [5]. The aggressive relations between the parties can be eliminated, as well as reduced the overall time required to complete the project; the project contractor interacts with the owner and oversees the design and construction of the project. This method is used most in projects such as water treatment plants or wastewater treatment [6].

The Construction Manager (CM). It consists of one person or a professional team. This depends on the management team's experience and the time of the project participation [5]. This method is used for big and complicated projects where the project organization cannot be run by the owner or the time is crucial, or the design is exceptional or creative, and the specifications are uncertain $[7,5]$. CM Provides advice to the owners in pre-construction work (e.g., engagement with design work to ensure optimum performance in material selection, systems, building procedures, site management consultancy, costs, schedule, security, and construction processes) or manage and supervise the work of contractors, including contract management and procurement. This advice may be given during the project life or in some parts of the project [8].

However, the construction manager CM system is categorized into two main groups according to the levels of engagement of the construction manager in the project and the amount of risk that the construction manager bears during services:

- The construction manager- advisor or agency CMA

- The construction manager at risk management CMAR.

Project manager (PM). The project manager works on behalf of the owner and oversees the project delivery daily. The best results are obtained from this relationship if the project owner and the project manager collaborate well and if the manager is properly empowered [9]. PM is considered a construction entity that offers a detailed list of services to an owner from the planning stage throughout the entire process. This can include maintenance and operations, as well as requiring a wide focus on experience and knowledge, collaborating with many eligible service providers. This can be viewed as the best choice in case of the absence of internal expertise, reductions in staffing are needed, and outsourcing issues are current [10]. A project manager may work in some other form of project delivery system or maybe an independent PDS form [11].

Separate prime contracts. In this method, the owner contracts directly with individual contractors, whom can be called "primary" contractor, since a general contractor does not coordinate their companies. Coordination between the primary contractors shall be by the internal personnel of the owner [8]. Thus, this method is to suffer from coordination problems [5], and in certain cases, the owner is responsible for overseeing and arranging their work or contract with the construction manager as an agent, who assists the owner in this coordination. The construction manager and the key contractors have no contractual arrangement [12]. 
Turnkey. The term turnkey will be used to define the global, more simplified arrangement of placement of all design, procurement, and construction duties on one contractor. Thus, no need to decide whether a defect has arisen because of the faulty design or construction of the works. In general, the contractor may assume responsibility for any fault that comes within the scope of the works. This makes turnkey contracts more attractive to employers [13]. This type of delivery system is like a design-build system, but the scope of the obligations of the contractors is usually broader than basic design, procurement, and construction. It covers activities, such as funding of the project, land procurement, and other activities that are not necessarily within the designconstruction [8] and may add the operational and/or maintenance obligations for the completed project. This approach has been successfully employed in power plants and public housing projects [2].

Force Account. In this method, the project owner acts as the prime contractor and carries out the work with its own forces [8] by using their own resources instead of operating to an external entity and providing supervision, materials, equipment, and labor in the field [14,15]. The procuring entity should ensure that work is carried out correctly through supervision of the works to be carried out, completion of the mission, verification of work performed and costs of the work, issue performance, and completion certificates. Force account may be used in maintenance work, in small projects, which are built to be used by the owner after completion [8], and places are distant such that reaching them is difficult, or emergencies that need to be treated promptly [7].

Build-own-operate-transfer (BOOT). It is a type of delivery system that enhances publicprivate partnerships in which a private firm is contracted to finance, design, build and operate the project for a certain period called the concession period [7]. (Normally 10-25years without project development time), and when this term ends, free transfers of assets to the government with the assurance that it is in acceptable condition [8]. This required ensuring that projects generate income in order to pay off their debts [7], and the duration of the contract period must be adequate in order to give the private party a fair return on their investments through usage charges [12]. The time between completion and transition allows the contractor to check the quality of the facilities and works performed and then prepare the employer workers to operate the facility [7].

\section{Green building (GB)}

GB can be defined as buildings that use key resources such as energy, water, materials, and land more effectively, designed, built, and operated more efficiently than conventional (nongreen) buildings to enhance their health, environmental, productivity, and economic performance. GB is seen in the construction industry as a form of technological and process innovation because it reorders a non-green building by integrating a variety of specific building technologies, practices, and materials to achieve sustainability [16]. There is a large variety of criteria that are critical to achieving green buildings and separating them from conventional innovations such as energy, site, indoor environment, land, and outdoor environment, material, water, innovation. There are many GB rating systems (GBRS) that provide owners the baseline to calibrate future performance, benchmarking for comparison with competitors, decision-making by creating a basis for choosing between the different solutions, and documentation by collect proof to comply with sustainable principles and regulations. Such as BREEAM, LEED, Green Globes, CASBEE. Most rating systems were initially voluntary and optional, but some countries have tended to make ratings compulsory [17].

\section{Barrier and Driving factors of green building}

With the rising number of sustainable and green projects, project delivery evaluation metrics have to be established, understood the impact of project delivery attributes on performance results, the delivery systems of the projects must be studied more specifically for green building projects 
in practical terms and with financial and time constraints. Designers, owners, and construction makers should understand better the relationship between PDS and green design goals to reduce the setbacks in implementing GB projects. The individual project characteristics should be the basis for PDS selection for green projects rather than identifying one PDS that to be used for all green projects. In order to determine the factors affecting the choice of the best delivery system for implementing green buildings, some construction projects were adopted in Iraq as a case study. Data were collected through (reviewing the contract for each project, meeting with project managers and engineers' specialists, monthly reports, and studying the methodology followed in the execution phase for the project). In addition, there are many studies identified the factors affecting the choice of project delivery systems for green building. After excluding repeated factors with the theoretical research, the Researcher classified these factors and distributed them to five groups, as shown in Table 1.

Table 1. The summary of the theoretical study and case studies for factors affecting the selection of delivery systems for green building projects.

\begin{tabular}{|c|c|}
\hline No. & Factors affecting the selection of project delivery systems for green building in construction projects \\
\hline \multicolumn{2}{|r|}{ 1.Factors related to the owner or his representative } \\
\hline $1-1$ & Delaying approval of design drawings and material specifications [18]. \\
\hline $1-2$ & Insufficient experience for the owner [19]. \\
\hline $1-3$ & The resources available to the owner to verify the quality of the design. \\
\hline $1-4$ & Choose an inefficient design team [20]. \\
\hline $1-5$ & The ability or desire of the owner to take responsibility for design management [21]. \\
\hline $1-6$ & The authority of the owner's staff regarding project management [21]. \\
\hline $1-7$ & Hiring an inefficient contractor $[22,20]$. \\
\hline $1-8$ & Owner's participation in project details, Does the owner want to get full participation in project details? [23]. \\
\hline $1-9$ & Existence of a system for training employees at the owner $[21,16]$ \\
\hline $1-10$ & Inaccuracy in costing before signing the contract [14]. \\
\hline $1-11$ & Provides financial liquidity and bank accounts for the owner $[16,18]$. \\
\hline $1-12$ & Misunderstanding of the project scope by the owner [22]. \\
\hline $1-13$ & Achieving owner satisfaction in general [16]. \\
\hline $1-14$ & The possibility of cost savings [Researcher]. \\
\hline \multicolumn{2}{|r|}{ 2- Factors associated with the designer } \\
\hline $2-1$ & The degree of impact of the complexity of the project $[22,23]$. \\
\hline $2-2$ & Use of advanced modern software to prepare designs $[21,16]$. \\
\hline $2-3$ & The effect of having previous experience in similar projects [23]. \\
\hline $2-4$ & Misunderstanding of owner requirements by design team [22]. \\
\hline $2-5$ & There is high monitoring and follow-up in the project [23]. \\
\hline $2-6$ & There is a difference between the design plans of all kinds [23]. \\
\hline $2-7$ & The flexibility of the project against changes during the construction period [23]. \\
\hline \multicolumn{2}{|r|}{ 3- The factors associated with the contractor } \\
\hline 3-1 & $\begin{array}{l}\text { Availability of qualified contractors, subcontractors, suppliers and craftsmen who have sufficient } \\
\text { qualifications }[22,16] \text {. }\end{array}$ \\
\hline $3-2$ & Repeated change of secondary contractors due to their inefficient work [Researcher]. \\
\hline 3-3 & The disputes of sub-contractors during the implementation period [Researcher]. \\
\hline $3-4$ & The contractor does not have the financial ability [16]. \\
\hline $3-5$ & Not having developed a project risk management plan [18]. \\
\hline $3-6$ & Weak management and supervision on site by the contractor for quality work [18]. \\
\hline \multicolumn{2}{|r|}{ 4- Contract-related factors } \\
\hline $4-1$ & Effect of the size of the project on the choice of the method of implementation [22]. \\
\hline $4-2$ & $\begin{array}{l}\text { Use negotiation for the team selection process, and contractual relationships between the owners and project } \\
\text { participants [22]. }\end{array}$ \\
\hline $4-3$ & Legal disputes between the contractor and the owner. \\
\hline $4-4$ & Impact of legal requirements, especially in the construction of public buildings [22]. \\
\hline $4-5$ & $\begin{array}{l}\text { The absence of incentive incentives for the contractor if the project is completed before the date specified in } \\
\text { the contract and with the required quality }[22,16,18] \text {. }\end{array}$ \\
\hline 4-6 & $\begin{array}{l}\text { Failure to secure a workable environment due to the contractor's ignorance or failure to apply the } \\
\text { occupational safety system in the project. }\end{array}$ \\
\hline & er Factors \\
\hline
\end{tabular}




\begin{tabular}{|c|l|}
\hline No. & Factors affecting the selection of project delivery systems for green building in construction projects \\
\hline $5-1$ & $\begin{array}{l}\text { Using modern software, electronic documentation, creating a database, and others that help in making the } \\
\text { right decisions in choosing the appropriate delivery system [16]. }\end{array}$ \\
\hline $5-2$ & $\begin{array}{l}\text { Working to coordinate between all parties to determine the time necessary to provide the materials or } \\
\text { services as soon as needed [18]. }\end{array}$ \\
\hline $5-3$ & The ability to gain knowledge from other companies. \\
\hline $5-4$ & Occurrence of economic crises in the country during the implementation of project. \\
\hline
\end{tabular}

\section{Methodology}

Based on the factors affecting the selection of the best delivery system for implementing green buildings illustrated in Table 1. A list of 37 factors with eight delivery systems was prepared, expert interviews who have extensive experience in the field of construction have been conducted to obtain the actual data to be used in building the proposed software system. Forty experts were invited to participate in this process. The interviews were conducted face to face with experts. The work sector for the participated experts, academic degrees, field of specialization, and the experience years for experts, have shown in Figures 1, 2, 3, and 4, respectively.

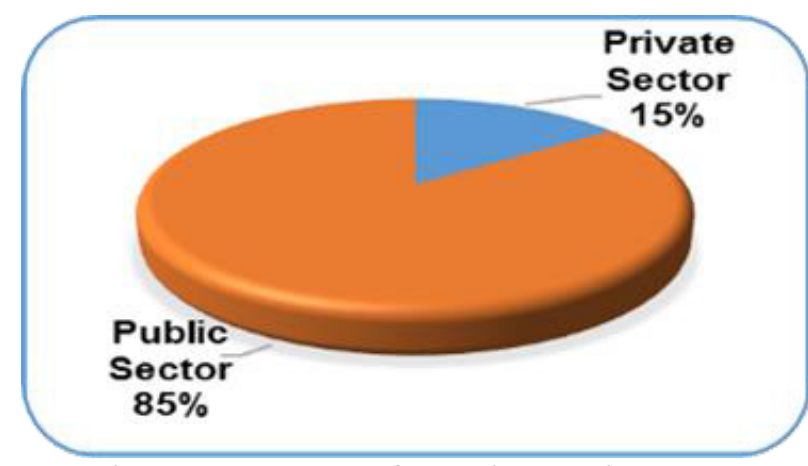

Figure 1. Experts from the work sector.

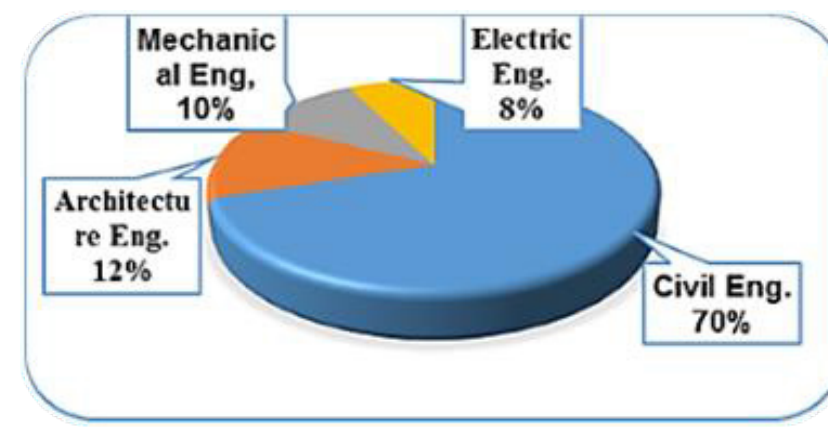

Figure 3. Field of specialization.

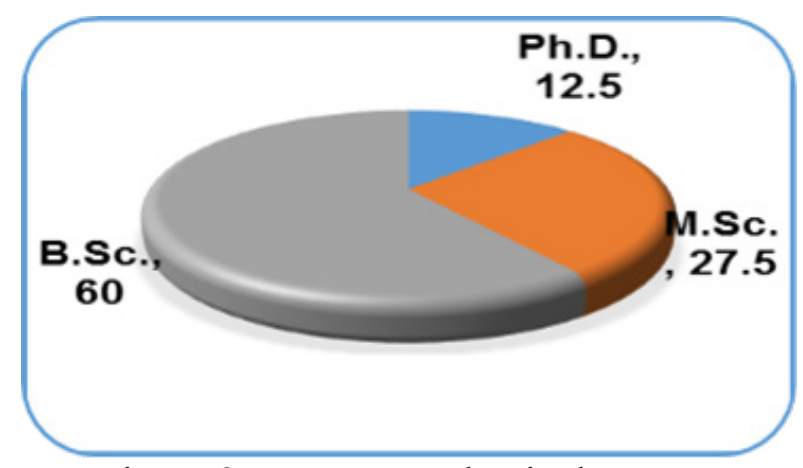

Figure 2. Experts academic degrees.

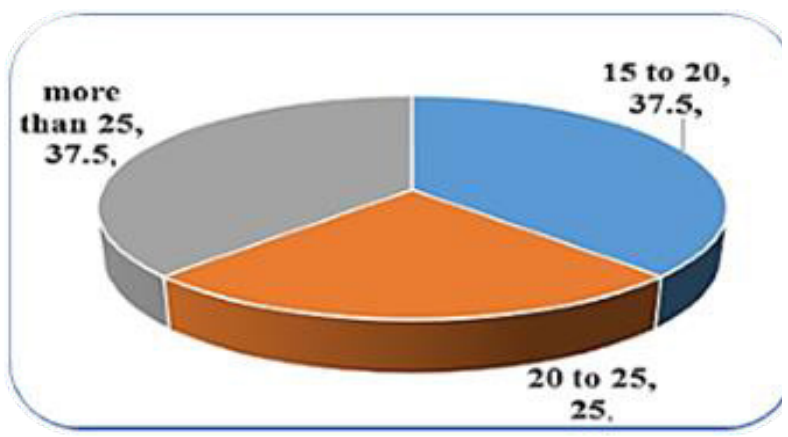

Figure 4. Experts experience years.

The responder asked to assess the importance by Likert scale in ascending order. According to the experts 'opinion, after using the statistical program SPSS (V.25) to calculate the (AM), (SD), for the list of factors, the results from these interviews identified the factors that fall within the high and very high range, which is $80 \%$ of the participating experts agreed upon as the most influential factors in choosing the appropriate implementation method. The Statistical Minitab (V.17) program was used to create a Pareto chart, to identify $20 \%$ of the factors that form $80 \%$ of the problem in choosing the best delivery systems in construction projects to rely on these factors in building the proposed system.

\section{Analyzing and Discussing Expert Answers}

According to the Pareto chart, seven influencing factors for each delivery system were identified, as shown in Tables 2 to 9. 
Table 2. Design- bid- build-The key affecting factors in green building projects.

\begin{tabular}{|l|l|c|c|c|}
\hline No. & \multicolumn{1}{|c|}{ The key affected factors } & AM & AMI \% & Category \\
\hline 1. & The contractor does not have the financial ability. & 4.17 & 14.57 & Contractor \\
\hline 2. & $\begin{array}{l}\text { The occurrence of economic crises in the country during the implementation } \\
\text { of the project. }\end{array}$ & 4.17 & 14.57 & $\begin{array}{c}\text { External } \\
\text { factors }\end{array}$ \\
\hline 3. & Choose an inefficient design team. & 4.15 & 14.50 & Owner \\
\hline 4. & Hiring an inefficient contractor. & 4.10 & 14.32 & Owner \\
\hline 5. & Providing financial liquidity and bank accounts for the owner & 4.10 & 14.32 & Owner \\
\hline 6. & The effect of having previous experience in similar projects & 3.97 & 13.87 & Designer \\
\hline 7. & The disputes of subcontractors during the implementation period & 3.97 & 13.87 & Contractor \\
\hline
\end{tabular}

Table 3. Design- builds-The key affecting factors in green building projects.

\begin{tabular}{|l|l|c|c|c|}
\hline No & \multicolumn{1}{|c|}{ The key affected factors } & AM & AMI\% & Category \\
\hline 1. & The contractor does not have the financial ability. & 4.22 & 15.01 & Contractor \\
\hline 2. & $\begin{array}{l}\text { The occurrence of economic crises in the country during the } \\
\text { implementation of the project. }\end{array}$ & 4.15 & 14.76 & $\begin{array}{c}\text { External } \\
\text { factors }\end{array}$ \\
\hline 3. & The effect of having previous experience in similar projects. & 4.02 & 14.30 & Designer \\
\hline 4. & Hiring an inefficient contractor. & 4.00 & 14.23 & Owner \\
\hline 5. & Choose an inefficient design team. & 3.95 & 14.05 & Owner \\
\hline 6. & The disputes of subcontractors during implementation period. & 3.90 & 13.87 & Contractor \\
\hline 7. & Providing financial liquidity and bank accounts for the owner. & 3.87 & 13.77 & Owner \\
\hline
\end{tabular}

Table 4. Turnkey-The key affecting factors in green building projects.

\begin{tabular}{|l|l|c|c|c|}
\hline No. & \multicolumn{1}{|c|}{ The effected factors } & AM & AMI \% & Category \\
\hline 1. & $\begin{array}{l}\text { The occurrence of economic crises in the country during the } \\
\text { implementation of the project. }\end{array}$ & 4.00 & 14.83 & $\begin{array}{c}\text { External } \\
\text { factors }\end{array}$ \\
\hline 2. & The contractor does not have the financial ability. & 3.97 & 14.71 & Contractor \\
\hline 3. & The effect of having previous experience in similar projects. & 3.92 & 14.53 & Designer \\
\hline 4. & Hiring an inefficient contractor. & 3.82 & 14.16 & Owner \\
\hline 5. & $\begin{array}{l}\text { The effect of the size of the project on the choice of the method of } \\
\text { implementation. }\end{array}$ & 3.82 & 14.16 & Contractor \\
\hline 6. & Use of advanced modern software to prepare designs. & 3.75 & 13.90 & Designer \\
\hline 7. & $\begin{array}{l}\text { Working to coordinate between all parties to determine the time necessary } \\
\text { to provide the materials or services as soon as needed. }\end{array}$ & 3.70 & 13.71 & $\begin{array}{c}\text { External } \\
\text { factors }\end{array}$ \\
\hline
\end{tabular}

Table 5. BOOT-The key affecting factors in green building projects.

\begin{tabular}{|l|l|c|c|c|}
\hline No. & \multicolumn{1}{|c|}{ The effected factors } & AM & AMI \% & Category \\
\hline 1. & $\begin{array}{l}\text { The occurrence of economic crises in the country during the implementation } \\
\text { of the project. }\end{array}$ & 4.07 & 15.36 & $\begin{array}{c}\text { External } \\
\text { factors }\end{array}$ \\
\hline 2. & The contractor does not have the financial ability. & 3.85 & 14.53 & Contractor \\
\hline 3. & Hiring an inefficient contractor. & 3.82 & 14.42 & Owner \\
\hline 4. & The effect of having previous experience in similar projects. & 3.72 & 14.04 & Designer \\
\hline 5. & Legal disputes between the contractor and the owner. & 3.70 & 13.96 & Contractor \\
\hline 6. & Not having developed a project risk management plan. & 3.67 & 13.85 & Contractor \\
\hline 7. & $\begin{array}{l}\text { The effect of the size of the project on the choice of the method of } \\
\text { implementation. }\end{array}$ & 3.67 & 13.85 & Contractor \\
\hline
\end{tabular}

Table 6. Construction manager-The key affecting factors in green building projects.

\begin{tabular}{|l|l|c|c|c|}
\hline No. & \multicolumn{1}{|c|}{ The effected factors } & AM & AMI \% & Category \\
\hline 1. & $\begin{array}{l}\text { The occurrence of economic crises in the country during the implementation } \\
\text { of the project }\end{array}$ & 4.12 & 15.56 & $\begin{array}{c}\text { External } \\
\text { factors }\end{array}$ \\
\hline 2. & The contractor does not have the financial ability & 3.90 & 14.73 & Contractor \\
\hline 3. & $\begin{array}{l}\text { Availability of qualified contractors, subcontractors, suppliers and craftsmen } \\
\text { who have sufficient qualifications }\end{array}$ & 3.75 & 14.16 & Contractor \\
\hline 4. & Providing financial liquidity and bank accounts for the owner & 3.70 & 13.97 & Owner \\
\hline
\end{tabular}




\begin{tabular}{|l|l|c|c|c|}
\hline No. & \multicolumn{1}{|c|}{ The effected factors } & AM & AMI \% & Category \\
\hline 5. & Choose an inefficient design team & 3.67 & 13.86 & Owner \\
\hline 6. & The effect of having previous experience in similar projects & 3.67 & 13.86 & Designer \\
\hline 7. & $\begin{array}{l}\text { Working to coordinate between all parties to determine the time necessary to } \\
\text { provide the materials or services as soon as needed }\end{array}$ & 3.67 & 13.86 & $\begin{array}{c}\text { External } \\
\text { factors }\end{array}$ \\
\hline
\end{tabular}

Table 7. Project manager-The key affecting factors in green building projects.

\begin{tabular}{|l|l|c|c|c|}
\hline No. & \multicolumn{1}{|c|}{ The effected factors } & AM & AMI \% & Category \\
\hline 1. & $\begin{array}{l}\text { The occurrence of economic crises in the country during the } \\
\text { implementation of the project }\end{array}$ & 3.97 & 15.27 & $\begin{array}{c}\text { External } \\
\text { factors }\end{array}$ \\
\hline 2. & The contractor does not have the financial ability & 3.82 & 14.69 & Contractor \\
\hline 3. & The effect of having previous experience in similar projects & 3.72 & 14.31 & Designer \\
\hline 4. & Inaccuracy in costing before signing the contract & 3.65 & 14.04 & Owner \\
\hline 5. & There is a difference between the design plans of all kinds & 3.62 & 13.92 & Designer \\
\hline 6. & $\begin{array}{l}\text { Working to coordinate between all parties to determine the time necessary } \\
\text { to provide the materials or services needed }\end{array}$ & 3.62 & 13.92 & $\begin{array}{c}\text { External } \\
\text { factors }\end{array}$ \\
\hline 7. & Repeated change of secondary contractors due to their inefficient work & 3.60 & 13.85 & Contractor \\
\hline
\end{tabular}

Table 8. Separate contractor-The key affecting factors in green building projects.

\begin{tabular}{|l|l|c|c|c|}
\hline No. & \multicolumn{1}{|c|}{ The effected factors } & AM & AMI \% & Category \\
\hline 1. & Providing financial liquidity and bank accounts for the owner & 3.77 & 14.45 & Owner \\
\hline 2. & There is a difference between the design plans of all kinds & 3.77 & 14.45 & Designer \\
\hline 3. & Repeated change of secondary contractors due to their inefficient work & 3.77 & 14.45 & Contractor \\
\hline 4. & The contractor does not have the financial ability & 3.77 & 14.45 & Contractor \\
\hline 5. & $\begin{array}{l}\text { The occurrence of economic crises in the country during the } \\
\text { implementation of the project }\end{array}$ & 3.77 & 14.45 & $\begin{array}{c}\text { External } \\
\text { factors }\end{array}$ \\
\hline 6. & Inaccuracy in costing before signing the contract & 3.62 & 13.88 & Owner \\
\hline 7. & $\begin{array}{l}\text { Availability of qualified contractors, subcontractors, suppliers, and } \\
\text { craftsmen who have sufficient qualifications }\end{array}$ & 3.62 & 13.88 & Contractor \\
\hline
\end{tabular}

Table 9. Force account-The key affecting factors in green building construction projects.

\begin{tabular}{|l|l|c|c|c|}
\hline No. & \multicolumn{1}{|c|}{ The effected factors } & AM & AMI \% & Category \\
\hline 1. & Providing financial liquidity and bank accounts for the owner. & 3.92 & 15.00 & Owner \\
\hline 2. & The effect of having previous experience in similar projects. & 3.82 & 14.62 & Designer \\
\hline 3. & $\begin{array}{l}\text { The occurrence of economic crises in the country during the } \\
\text { implementation of the project. }\end{array}$ & 3.80 & 14.54 & $\begin{array}{c}\text { External } \\
\text { factors }\end{array}$ \\
\hline 4. & $\begin{array}{l}\text { The ability or desire of the owner to take responsibility for design } \\
\text { management. }\end{array}$ & 3.75 & 14.35 & Owner \\
\hline 5. & Achieving owner satisfaction in general. & 3.65 & 13.97 & Owner \\
\hline 6. & Choose an inefficient design team. & 3.62 & 13.85 & Owner \\
\hline 7. & Not having developed a project risk management plan. & 3.57 & 13.66 & Contractor \\
\hline
\end{tabular}

\section{Building the Proposed System}

It was adopted the basics of the methodology of the Evaluation of Alternatives Using a Decision Tree in the design of the proposed system to select the best delivery system for executing the green building. For the purpose of evaluating alternatives, there must be a series of decisions in which the outcome from one stage is essential to the next step of decision-making. The decision tree is represented from left to right and includes each possible decision and outcome, as shown in Figure 5 [24]. The decision tree contains:

- There will be more than one stage for choosing the alternative.

- Choosing an alternative at one-stage leads to another.

- Set the results expected from the decision at each stage.

- Probability estimates for each outcome. 


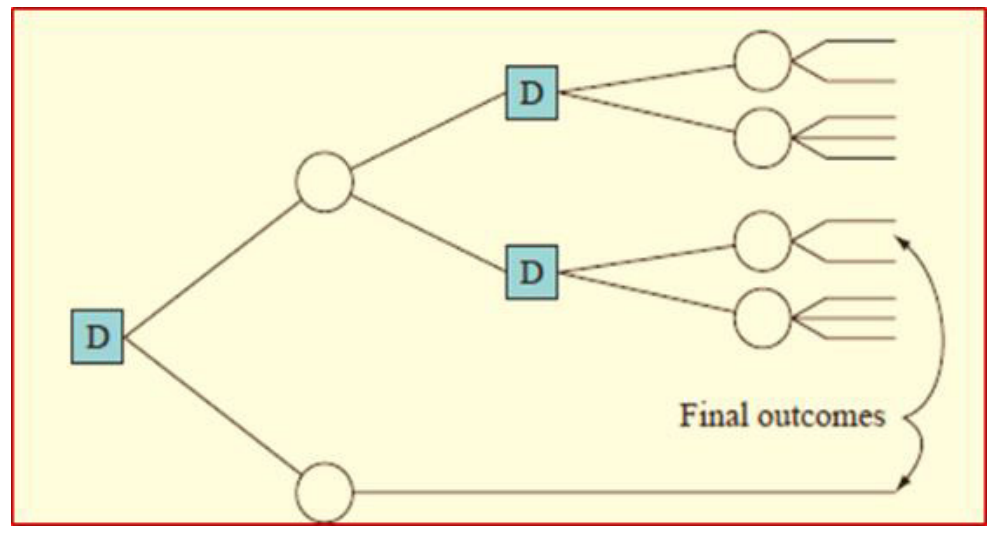

Figure 5. Decision Tree structure [24].

These probabilities must sum to 1.0 for each set of outcomes (branches) that result from a decision as in Equation 1.

$\sum_{(\mathrm{i}=1)}^{(\mathrm{i}=\mathrm{m})} \mathrm{P}(\mathrm{Xi})=1.0$

- Usually, each branch of a decision tree has some estimated economic value and are shown to the right of each outcome branch. This value and probability evaluate on each outcome branch are used in calculating the expected economic value $(\mathrm{EV})$ of each decision branch as in Equation (2). This process is called solving the tree or rollback.

$\mathrm{E}($ decision $)=\sum$ (outcome estimate $) \times \mathrm{P}($ outcome $)$

Where the summation is taken over all possible outcomes for each decision alternative. Outcome estimate $=$ User rating (very high $=1$, high $=0.8$, medium $=0.6) . \mathrm{P}($ outcome $)=\mathrm{AMI} \%$ $=\mathrm{AM}$ for each key factor resulting from Pareto chart $/ \sum \mathrm{AM}$ for key factors resulting from the Pareto chart.

- At any decision node, choose the best E (decision) value.

- Proceed to move to the left of the tree to the root decision in order to choose the best alternative. Follow the best decision path through the tree [24].

\section{The Program Operation}

Three software connected in the system, Visual Basic, Word, and Excel, to create an integrated system presenting process facilitating of using the proposed system by engineers involved applications in construction projects. The Program operation involves the following:

- System language (English to Arabic), user's name, and password to protect the program.

- After entering the user's name and password, forms will appear containing delivery systems criteria (which we obtained from Pareto chart). There are three choices, very high, high, and medium, which represent the degree of influence of each criterion $(1,0.8$, and $0.6)$, respectively. The user determines the degree of influence, and then the system calculates the sum of the product of the degree of influence with the weight of each criterion AMI \%. The method which has a higher weight will be the best

- The first stage includes choosing the best supervisory method (project manager, construction manager), and then select one of the delivery systems as shown in Figure 6. 


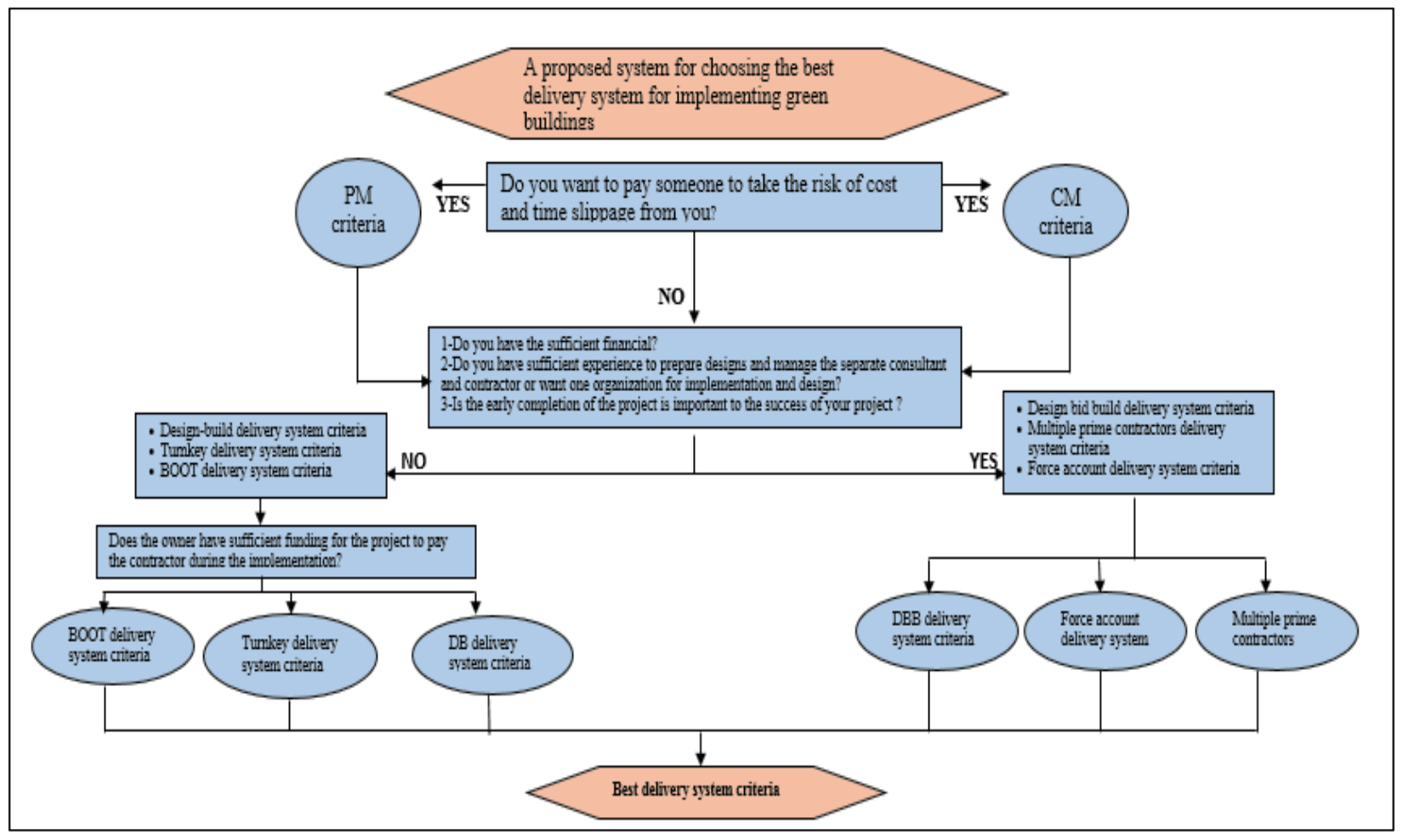

Figure 6. Chart for program operation.

\section{Conclusions and Recommendations}

Based on the results of this study, the following points can be concluded:

- The main influential factors in the selection of the best method for implementing green buildings are: (The occurrence of economic crises in the country), (availability of financial capacity for the contractor and the owner), (the lack of previous experience in similar projects), (hiring an incompetent contractor), (differences between design drawings among all disciplines), and (providing qualified contractors, subcontractors, suppliers, and craftsmen with sufficient qualifications early in the project).

- Choosing the appropriate way to implement the project has a significant impact on the success of task management in the construction project, the high quality, cost, and time required to complete the construction project through coordination between all parties in the early stages of the project.

Based on the research results, the following points are suggested as recommendations for the research:

- Applying the proposed system to choose the best method for implementing green buildings from the start of the construction project and providing the necessary financial allocations to implement the proposed system in construction projects.

- Increasing governmental or high authorities' support, training, and qualifying engineering staff, holding scientific conferences to raise awareness of the green building principles and the future environmental benefits of green buildings, and providing the raw materials needed for green building projects in local markets.

- use of information communication technology in construction projects to contribute to reducing execution problems and increasing coordination between all parties involved in the project (the project manager, design team, and contractor) from the beginning of the construction project life cycle to the end

- The necessity of early participation of the contractor and suppliers in the project (informally or contractually) at the design stage. 


\section{References}

[1] Tariku, R. 2016. Project delivery systems and their effects on cost and time overrun on Ethiopian road authority projects. M.Sc. Thesis, Addis Ababa University.

[2] ASCE. 2012. Quality in the constructed project: A guide for owners, designers, and constructors. Reston, VA: American Society of Civil Engineers.

[3] Gajurel, A. 2014. Performance-based contracts for road projects: Comparative analysis of different types. Springer India.

[4] Hanna, A. S. 2016. Benchmark performance metrics for integrated project delivery. Journal of Construction Engineering and Management, 142(9), 04016040.

[5] Debella, D. M. 2004. Construction delivery systems: A comparative analysis of the performance of systems within school districts. M.Sc. Thesis, School of Engineering, University of Pittsburgh.

[6] Gade, D. R. 2018. An investigative analysis of skill sets for different delivery methods in the building industry. M.Sc. Thesis, Civil, Construction, and Environmental Engineering, Iowa State University.

[7] Mesfin, A., 2014, A Study on Construction contract risk management practices in Ethiopian building construction projects. M.Sc. Thesis, Addis Ababa University.

[8] Bennett, F. 2007. The Management of construction: A project life cycle approach. Journal of Chemical Information and Modeling, 53(9), 12-36.

[9] Turner, J. R., and Müller, R. 2004. Communication and co-operation on projects between the project owner as principal and the project manager as agent. European management journal, 22(3), 327.

[10] Pakkala, P. 2002. Innovative project delivery methods for infrastructure. Finish Road Enterprise, Helsinki, 19.

[11] Raimi, T. I. 2016. Application of construction management, procurement and project delivery systems by private housing developers in Nigeria for sustainable development. Procs. of the Joint International Conference (JIC) on 21st Century Human Habitat: Issues, Sustainability and Development, Akure, Nigeria, 706-717

[12] Almazroa, D. A. 2004. Project delivery system decision framework using the weighting factors and analytic hierarchy process methods. Ph.D. Thesis, School of Engineering, University of Pittsburgh.

[13] Huse, J. A. 2002. Understanding and negotiating turnkey and EPC contracts. Sweet and Maxwell.

[14] Tekka, R. S. 2018. Economic Empowerment of local skilled labour through Force Account in Building Renovation. Journal of Civil, Construction and Environmental Engineering, 2(6), 159.

[15] Molenaar, K., Harper, C., and Yugar-Arias, I. 2014. Guidebook for selecting alternative contracting methods for roadway projects: Project delivery methods, procurement procedures, and payment provisions. Transportation Pooled Fund Program Study TPF-5 (260), 410.

[16]Darko, A., Chan, A. P. C., Ameyaw, E. E., He, B. J., and Olanipekun, A. O. 2017. Examining issues influencing green building technologies adoption: The United States green building experts' perspectives. Energy and Buildings, 144, 320-332.

[17] Shan, M., and Hwang, B. G. 2018. Green building rating systems: Global reviews of practices and research efforts. Sustainable Cities and Society, 39, 172-180.

[18]Hwang, B. G., and Tan, J. S. 2012. Green building project management: obstacles and solutions for sustainable development. Sustainable Development, 20(5), 335-349.

[19] Chan, A. P. C., Darko, A., and Ameyaw, E. E. 2017. Strategies for promoting green building technologies adoption in the construction industry-An international study. Sustainability, 9(6), 969.

[20]Li, Y., Song, H., Sang, P., Chen, P. H., and Liu, X. 2019. Review of Critical Success Factors (CSFs) for green building projects. Building and Environment, 158, 182-191. 
[21] Bilec, M., and Ries, R. 2007. Preliminary study of green design and project delivery methods in the public sector. Journal of Green Building, 2(2), 151-160.

[22] Robichaud, L. B., and Anantatmula, V. S. 2011. Greening project management practices for sustainable construction. Journal of Management in Engineering, 27(1), 48-57.

[23] Zhang, J., Li, H., Olanipekun, A.O. and Bai, L., 2019. A successful delivery process of green buildings: the project owners' view, motivation and commitment. Renewable energy, 138, 651-658.

[24] Leland Blank, P.E. and Anthony Tarquin, P.E., 2012. Engineering economy. Methods, 1(2), p.4. 